\title{
Mineral Estimation of Indian Horse Chestnut (Aesculus indica) Seeds after Crude Saponin / Aescin Extraction
}

\author{
Manju Lata Mishra ${ }^{1}$, Sangita Sood ${ }^{1}$, Anil Sood $^{2}$, Bikram Singh $^{2}$, \\ Ashu Gulati ${ }^{2}$ and U.N. Shukla ${ }^{3}$ \\ ${ }^{1}$ FSN\&T, College of Home Science, CSK HPKV, Palampur (H.P.), India \\ ${ }^{2}$ CSIR-Institute of Himalayan Bioresource Technology, Palampur, (H.P.), India \\ ${ }^{3}$ Department of Agronomy, College of Agriculture, Agriculture University, \\ Jodhpur, (Raj.), India \\ *Corresponding author
}

\begin{abstract}
A B S T R A C T
\section{Keywords}

Minerals, Saponin,

Techniques, Treatments

and Toxic

Article Info

Accepted:

16 August 2018

Available Online:

10 September 2018

Aesculus indica seeds were various treated under different processing techniques to achieve maximum removal its saponin/ aescin content which is toxic if consumed seeds as raw. The mineral viz. calcium, manganese, zinc, iron and copper were estimated. The methods used were as Fresh sample $\left(\mathrm{T}_{0}\right)$, Percolator/ cold extraction $\left(\mathrm{T}_{1}\right)$, Roasted $\left(\mathrm{T}_{2}\right)$, Soxhlet $\left(\mathrm{T}_{3}\right)$, Microwave cooking whole seed (MW), Microwave cooking crush seed (MC) Pressure cooking $(\mathrm{PW}), 10$ minute whole seed boiling $\left(\mathrm{B}_{1} \mathrm{~W}\right), 20$ minute whole seed boiling $\left(\mathrm{B}_{2} \mathrm{~W}\right), 30$ minute whole seed boiling $\left(\mathrm{B}_{3} \mathrm{~W}\right), 10$ minute crush seed boiling $\left(\mathrm{B}_{1} \mathrm{C}\right)$, 20 minute crush seed boiling $\left(\mathrm{B}_{2} \mathrm{C}\right), 30$ minute crush seed boiling $\left(\mathrm{B}_{3} \mathrm{C}\right)$. It was found that the treatment $\mathrm{T}_{3}$ contains more Calcium $(34.80 \mathrm{mg} / 100 \mathrm{~g})$ comparatively. Manganese was found maximum in $\mathrm{T}_{1}$ and $\mathrm{T}_{2}$ treatments as 2.50 and $2.30 \mathrm{mg} / 100 \mathrm{~g}$ respectively, which were almost similar when compared with other treatment. Zinc content in $\mathrm{B}_{2} \mathrm{~W}$ was high as $782.40 \mathrm{mg} / 100 \mathrm{~g}$. Iron value of MC was reported as $64.00(\mathrm{mg} / 100 \mathrm{~g})$ upper limits. And copper as $1.20 \mathrm{mg} / 100 \mathrm{~g}$ in MW treatment.
\end{abstract}

\section{Introduction}

In various region of our country, Indian Horse Chestnut scientifically identified as Aesculus indica which is called as khanor, bankhor, tatwakhar in Himachal Pradesh, fangar, bankhor, gugu, kanor, pankor in Hindi, hane, hanudun in Kashmir, kanur, gun, khanor in Punjab (Parmar and Kaushal, 1982). Its general occurrence at high altitude of Himalayan forest area. The tree is tall and deciduous in nature. The fruits are shiny dark chocolate to brown in color, having smooth ovoids and each seed weighed approximately 11-21g in weight (Sood and Mishra, 2014). The seeds of the Indian horse chestnut can be used as food, feed and fodder. Bark is used for lowering temperature, ulcer suppression. It possessed medicinal as well as nutritional values. Besides, the seeds or fruit is used for neuralgia, rectal complaints, skin disease, hemorrhoids and headache (Sood et al., 2015). It contains natural toxic component i.e. saponin/ aescin as well as flavanoids, 
glycosides, tannins and phenolic compounds (Kaur et al., 2011), which may lethal for human consumption if use without processing. The nuts were dehulled and crushed into detoxify by traditional techniques like steeping in water for 5 to 7 days consecutively, to detoxify its toxicity and dried in sunlight. It was grounded to made flour known as tatwakhar or processed flour (Mishra et al., 2018a), whereas the improved different pretreatments like soaking, blanching, cooking, pressure cooking and less saponin containing flour was used for its sensory characteristics. The toxic effects include muscle contraction, weakness, need coordination, dilated pupils, vomiting, diarrhoea, depression, paralysis and coma (Thakur et al., 2015). It is also given to the horses experiencing colic disorder and the oil contained 2.02 per cent in seed (Majeed et al., 2010), is used to alleviate rheumatism (Zhang et al., 2010). The mineral values of fresh flour of the seed were reported as calcium (8.20), phosphorus (19.00), potassium (81.00), copper (0.60), manganese (0.50), iron (8.50) and zinc (705.90) (mg/100g) by (Mishra et al., 2018b). Although, only mineral content of fresh seed flour is documented not giving much emphasis on the various pretreatments done for mineral extraction. Hence, in the present study keeping in view its importance, the following investigation was done.

\section{Materials and Methods}

Firstly, fresh seed sample was used for the extraction of crude saponin/ aescin content. For extracting the same, various treatments were done to achieve maximum amount. Then this treated flour was digested as prepared for the estimation minerals.

\section{Digestion}

Took $150 \mathrm{ml}$ conical flask and one gram of translucently milled sample was taken in it.
Add $25 \mathrm{ml}$ of diacid mixture $\left(\mathrm{HNO}_{3}: \mathrm{HClO}_{4}\right.$ in $5: 1 \mathrm{v} / \mathrm{v}$ ) and kept it for overnight. The acid sample was digested on hot plate till the white or clear precipitates were not settling down at base. Then the crystals were melted by diluting with the use of double distilled water. The substances were passing through a Whatman filter paper No. 42 and made up to $25 \mathrm{ml}$ volume with double distilled water. The sample was ready for the determination of copper, zinc, manganese, and iron by means of atomic absorption spectrophotometer, Model 3100, Perkin Elmer. Flame photometer, Mediflame, 127 was used for the Calcium estimation. All the values were taken as an average of triplicate readings.

\section{Results and Discussion}

\section{Mineral composition of flour after extraction}

In Table 1, the mineral content were estimated in the sample and reported as the calcium content in $\mathrm{T}_{3}$ was found maximum with the value $34.80 \mathrm{mg} / 100 \mathrm{~g}$ followed by $\mathrm{T}_{1}$ which was analyzed as $26.40 \mathrm{mg} / 100 \mathrm{~g}$. In $\mathrm{T}_{2}$, it came out to be $25.4 \mathrm{mg} / 100 \mathrm{~g}$. In $\mathrm{B}_{3} \mathrm{~W}$, the value for the same content was found as $19.50 \mathrm{mg}$ followed by MW (16.60 mg). In the treatments $\mathrm{PW}, \mathrm{B}_{2} \mathrm{~W}$ and $\mathrm{B}_{1} \mathrm{C}$ the values for calcium ranged from 13.40 to $14.30 \mathrm{mg} / 100 \mathrm{~g}$.

The values were decreased in $\mathrm{MC}$ i.e. 12.60 $\mathrm{mg}$ then followed by $\mathrm{B}_{3} \mathrm{C}$ contains $12.10 \mathrm{mg}$. On the contrary, the $\mathrm{T}_{0}$ contains lowest $(8.20$ $\mathrm{mg} / 100 \mathrm{~g}$ ) amount of calcium. In $\mathrm{T}_{2}$ and $\mathrm{T}_{1}$ had the highest range of manganese content i.e. $2.30-2.50 \mathrm{mg} / 100 \mathrm{~g}$ but in $\mathrm{MC}$, $\mathrm{PW}$ and $\mathrm{B}_{1} \mathrm{~W} \mathrm{~B}_{2} \mathrm{~W}, \mathrm{~B}_{3} \mathrm{~W}, \mathrm{~B}_{1} \mathrm{C}, \mathrm{B}_{2} \mathrm{C}, \mathrm{B}_{3} \mathrm{C}$ varied the manganese content from 0.60 to $1.20 \mathrm{mg} / 100$ $\mathrm{g}$ of flour. Statistically these are at par and different treatments showed no effect by the different method of extraction. On the other hand, $\mathrm{T}_{0}$ and $\mathrm{MW}$ contain alike values $(0.50$ $\mathrm{mg} / 100 \mathrm{~g}$ ) in the flour. The maximum content 
(782.40 mg/100 g) of zinc was found in $\mathrm{B}_{2} \mathrm{~W}$ followed by $\mathrm{B}_{3} \mathrm{~W}$ in which it was estimated as $715.50 \mathrm{mg} / 100 \mathrm{~g}$. In $\mathrm{T}_{0}$, the zinc content was analyzed as $705.90 \mathrm{mg} / 100 \mathrm{~g}$ whereas; $\mathrm{B}_{1} \mathrm{~W}$ and $\mathrm{B}_{2} \mathrm{C}$ contained 680.60 and $630.40 \mathrm{mg} / 100$ $\mathrm{g}$ respectively. In PW, the zinc content was $561.50 \mathrm{mg}$ in $100 \mathrm{~g}$ of flour. Statistically, there was comparative difference found among the treatments. But there was drastic decline in $\mathrm{B}_{3} \mathrm{C} 151.70 \mathrm{mg}$ was found in the zinc content. In case of $\mathrm{B}_{1} \mathrm{C}, \mathrm{MC}$ and $\mathrm{T}_{1}$; the values ranged from $4.805 .30 \mathrm{mg} / 100 \mathrm{~g}$ was found. The lowest manganese content was found in $\mathrm{T}_{2}$ i.e. $3.00 \mathrm{mg} / 100 \mathrm{~g}$; whereas $\mathrm{T}_{3}$ and $\mathrm{MC}$ the values were laid in the same range with $\mathrm{T}_{2}$ (3.20 to $\left.3.50 \mathrm{mg} / 100 \mathrm{~g}\right)$. The iron content was found highest in the treatment $\mathrm{MC}$ i.e. $64 \mathrm{mg} / 100 \mathrm{~g}$ thereafter, a significant difference was observed in $\mathrm{T}_{3}(42.20 \mathrm{mg})$ and
$\mathrm{T}_{1}(43.00 \mathrm{mg} / 100 \mathrm{~g})$ method. In $\mathrm{T}_{2}$, the iron content was decreased to $32.20 \mathrm{mg}$ whereas, the treatment $\mathrm{B}_{3} \mathrm{C}$ contained $27.50 \mathrm{mg} / 100 \mathrm{~g}$ of flour; $\mathrm{B}_{2} \mathrm{~W}$ was analyzed to $23.30 \mathrm{mg} ; \mathrm{B}_{1} \mathrm{C}$ contained $20.20 \mathrm{mg}$ followed by the $\mathrm{B}_{1} \mathrm{~W}$ where the values were established at 13.20 $\mathrm{mg} / 100 \mathrm{~g}$. The $\mathrm{T}_{0}$ and $\mathrm{B}_{3} \mathrm{~W}$ contained 8.50 and $9.40 \mathrm{mg} / 100 \mathrm{~g}$ respectively. The lowest values were shared by the treatments PW $(6.60 \mathrm{mg})$, MW (6.70 mg) and $\mathrm{B}_{2} \mathrm{C}$ contains $7.00 \mathrm{mg}$ iron per $100 \mathrm{~g}$ of flour. The treatment $\mathrm{MW}$ contained maximum copper content i.e. 1.20 $\mathrm{mg} / 100 \mathrm{~g}$ of flour. Whereas, $\mathrm{B}_{1} \mathrm{C}$ and $\mathrm{B}_{2} \mathrm{C}$ values were analyzed as 0.80 and $1.00 \mathrm{mg} / 100$ g, respectively. In treatments $\mathrm{T}_{3}, \mathrm{~T}_{1}, \mathrm{MC}, \mathrm{PW}$, $\mathrm{B}_{1} \mathrm{~W}, \mathrm{~B}_{2} \mathrm{~W}, \mathrm{~B}_{3} \mathrm{~W}, \mathrm{~B}_{3} \mathrm{C}$ and $\mathrm{T}_{0}$ the copper content varied from 0.60 to $0.70 \mathrm{mg} / 100 \mathrm{~g}$ of flour. The copper content was found lowest in $\mathrm{T}_{2}(0.50 \mathrm{mg} / 100 \mathrm{~g})$ flour.

Table.1 Mineral composition of flour after extraction of crude saponin/aescin

\begin{tabular}{|c|c|c|c|c|c|c|}
\hline $\begin{array}{l}\text { SI } \\
\text { no }\end{array}$ & Treatments & $\begin{array}{l}\text { Calcium } \\
\text { (mg/100g) }\end{array}$ & $\begin{array}{c}\text { Manganese } \\
\text { (mg/100g) }\end{array}$ & $\begin{array}{c}\text { Zinc } \\
(\mathrm{mg} / 100 \mathrm{~g})\end{array}$ & $\begin{array}{c}\text { Iron } \\
(\mathrm{mg} / 100 \mathrm{~g})\end{array}$ & $\begin{array}{c}\text { Copper } \\
(\mathrm{mg} / 100 \mathrm{~g})\end{array}$ \\
\hline 1 & Soxhlet $\left(\mathbf{T}_{3}\right)$ & $34.80^{\mathrm{a}}$ & $0.60^{\mathrm{d}}$ & $3.20^{\mathrm{j}}$ & $42.20^{\mathrm{b}}$ & $0.60^{\mathrm{bc}}$ \\
\hline 2 & $\operatorname{Roasted}\left(\mathbf{T}_{2}\right)$ & $25.40^{\mathrm{c}}$ & $2.30^{\mathrm{a}}$ & $3.00^{j}$ & $32.20^{\mathrm{c}}$ & $0.50^{c}$ \\
\hline 3 & Percolator/ cold extraction $\left(T_{1}\right)$ & $26.40^{\mathrm{b}}$ & $2.50^{\mathrm{a}}$ & $5.30^{\mathrm{i}}$ & $43.00^{b}$ & $0.60^{\mathrm{bc}}$ \\
\hline 4 & Microwave cooking whole seed(MW) & $16.60^{\mathrm{e}}$ & $0.50^{\mathrm{e}}$ & $3.50^{\mathrm{j}}$ & $6.70^{i}$ & $1.20^{\mathrm{a}}$ \\
\hline 5 & Microwave cooking crush seed(MC) & $12.60^{\mathrm{i}}$ & $1.10^{\mathrm{bcd}}$ & $4.80^{\mathrm{i}}$ & $64.00^{\mathrm{a}}$ & $0.70^{\mathrm{bc}}$ \\
\hline 6 & Pressure cooking $(\mathbf{P W})$ & $14.30^{\mathrm{fg}}$ & $0.60^{\mathrm{d}}$ & $561.50^{f}$ & $6.60^{\mathrm{i}}$ & $0.70^{\mathrm{bc}}$ \\
\hline 7 & 10 minute whole seed boiling $\left(B_{1} W\right)$ & $13.70^{\mathrm{gh}}$ & $1.00^{\mathrm{bcd}}$ & $680.60^{d}$ & $13.20^{\mathrm{g}}$ & $0.70^{\mathrm{bc}}$ \\
\hline 8 & 20 minute whole seed boiling $\left(B_{2} W\right)$ & $13.90^{\operatorname{tgh}}$ & $0.90^{\text {bcd }}$ & $782.40^{\mathrm{a}}$ & $23.30^{\mathrm{e}}$ & $0.70^{\mathrm{bc}}$ \\
\hline 9 & 30 minute whole seed boiling $\left(B_{3} W\right)$ & $19.50^{\mathrm{d}}$ & $0.70^{\mathrm{cd}}$ & $715.50^{b}$ & $9.40^{\mathrm{h}}$ & $0.60^{\mathrm{bc}}$ \\
\hline 10 & 10 minute crush seed boiling $\left(B_{1} C\right)$ & $13.40^{\mathrm{h}}$ & $0.80^{\mathrm{bcd}}$ & $23.20^{\mathrm{h}}$ & $20.20^{f}$ & $0.80^{\mathrm{b}}$ \\
\hline 11 & 20 minute crush seed boiling $\left(B_{2} C\right)$ & $14.10^{\mathrm{fgh}}$ & $0.60^{\mathrm{d}}$ & $630.40^{e}$ & $7.00^{\mathrm{i}}$ & $1.00^{b}$ \\
\hline 12 & 30 minute crush seed boiling $\left(B_{3} C\right)$ & $12.10^{\mathrm{j}}$ & $1.20^{\mathrm{bcd}}$ & $151.70^{\mathrm{g}}$ & $27.50^{\mathrm{d}}$ & $0.60^{\mathrm{bc}}$ \\
\hline 13 & Fresh sample $\left(\mathbf{T}_{0}\right)$ & $8.20^{\mathrm{k}}$ & $0.50^{\mathrm{e}}$ & $705.90^{c}$ & $8.50^{\mathrm{h}}$ & $0.60^{\mathrm{bc}}$ \\
\hline & $\mathrm{CD}(\mathrm{P} \leq \mathbf{0 . 0 5})$ & 0.49 & 0.42 & 0.74 & 1.00 & 0.28 \\
\hline
\end{tabular}

Each value represents mean of three replicates. In the same column, significant differences according to CRD are indicated by different letters. Same letter represent that their values are at par

Concisely, the effect of different methods of processing on minerals was found more when compared with control i.e. $\mathrm{T}_{0}$. In $\mathrm{T}_{3}$, the calcium content was found to be high than other treatments. Manganese content was found maximum in $\mathrm{T}_{1}$. In $\mathrm{B}_{2} \mathrm{~W}$, the zinc element was found high. Iron present more in $\mathrm{MC}$ and copper element showed highest value 
in MW. The lesser values in $T_{0}$ were because of the fact that the elements might be in a complex form and they were not exist in Free State. But when heat treatment was given to the seeds, there might be availability of free ions after the breakdown of complex structure.

It can be concluded that the Indian horse chestnut seeds when treated by different processing techniques, all the minerals contents were more available than the fresh sample i.e. Calcium content was more in soxhlet extraction, same like in case of manganese and iron, exceptionally zinc content of fresh sample was found higher rather than the other treatments. The values of the copper of all treatment weren't extreme so much when compared to the fresh sample. Hence there is more availability of minerals in the pretreated flour.

\section{References}

Kaur, L., Joseph, L., Mathew, G. 2011. Phytochemical analysis of leaf extract of Aesculus indica. International Journal of Pharmacy and Pharmaceutical Sciences 3(5): 232-234.

Majeed, M., Khan, M.A., Bashir, A and Hussain, A. 2010. Nutritional value and oil content of Indian horse-chestnut seed. Global Journal of Science Frontier Research 10(4):17-19.

Mishra, M.L., Sood S. and Shukla U.N. 2018b. Phyto-nutritional and mineral composition of Indian Horse Chestnut (Aesculus indica) seeds Journal of Pharmacognosy and Phytochemistry 7(1): 2159-2162.

Mishra, M.L., Sood, S. and Shukla, U.N. 2018a. Standardization, Development and Proximate Composition of Baked Value Added Products by Using Indian Horse Chestnut (Aesculus indica) Flour. Int. J. Curr. Microbiol. App. Sci 7(2): 1449-1458.

Parmar, C. and Kaushal, M.K. 1982. Aesculus indica In: Wild Fruits. Kalyani Publishers, New Delhi, India p. 6-9.

Sood S. and Mishra M.L. (2014) Studies on physical attributes of Indian horse chestnut (Aesculus indica). Indian Journal of Social and Natural Sciences 3: $68-73$.

Sood, S., Mishra, M., Sood, A. and Thakur, V. 2015. Hypoglycaemic and hypocholesterolimic efficacy of horse chestnut (Aesculus indica) using rat model. Journal of Clinical Nutrition and Dietetics 1(1):1-8.

Thakur, N.S., Kumar, P. and Joshi, V.K. 2015. Improvement of traditional methods for the development of edible flour from Indian horse chestnut (Aesculus indica). Intl. J. Food. Ferment. Technol 5(2): 169-176.

Zhang, Z., Shiyou, L. and Xiao-Yuan, L. 2010. An overview of genus Aesculus L.: Ethanobotany, phytochemistry and pharmacological Activities. Pharmaceutical Crops 1: 24-51.

\section{How to cite this article:}

Manju Lata Mishra, Sangita Sood, Anil Sood, Bikram Singh, Ashu Gulati and Shukla, U.N. 2018. Mineral Estimation of Indian Horse Chestnut (Aesculus indica) Seeds after Crude Saponin / Aescin Extraction. Int.J.Curr.Microbiol.App.Sci. 7(09): 2193-2196. doi: https://doi.org/10.20546/ijcmas.2018.709.270 